THE ROLE OF IMMIGRANT WOMEN IN THEIR FAMILIES' SETTLEMENT

IN CANADA

by

\author{
Assel Baitubayeva \\ BSS, KIMEP University, 2003 \\ MIR, KIMEP University, 2005 \\ MA, Almaty Management University, 2014 \\ A Major Research Paper \\ Presented to Ryerson University \\ in partial fulfillment of the requirements for the degree of \\ Master of Arts \\ in the Program of \\ Immigration and Settlement Studies
}

Toronto, Ontario, Canada, 2017

(C) Assel Baitubayeva, 2017 


\section{AUTHOR'S DECLARATION FOR ELECTRONIC SUBMISSION OF A MAJOR RESEARCH PAPER (MRP)}

I hereby declare that I am the sole author of this Major Research Paper. This is a true copy of the MRP, including any required final revisions.

I authorize Ryerson University to lend this MRP to other institutions or individuals for the purpose of scholarly research.

I further authorize Ryerson University to reproduce this MRP by photocopying or by other means, in total or in part, at the request of other institutions or individuals for the purpose of scholarly research.

I understand that my MRP may be made electronically available to the public.

Assel Baitubayeva 


\title{
THE ROLE OF IMMIGRANT WOMEN IN THEIR FAMILIES' SETTLEMENT \\ IN CANADA
}

\author{
Assel Baitubayeva \\ Master of Arts 2017 \\ Immigration and Settlement Studies \\ Ryerson University
}

\begin{abstract}
This paper examines the invisible role of immigrant women in their families' settlement in Canada. The majority of immigrants in Canada are women, whose traditional and newly accepted family roles and duties in the receiving country make a significant contribution to settlement of their husbands and children. This study demonstrates that women's physical, financial, social and emotional support helps their family members to adapt to the new environment smoother. Newcomer women often delay their own settlement for the sake of their families' well-being. Studies of immigrant women's significant contribution to their families' settlement would allow to develop effective settlement programs to facilitate settlement of whole families.
\end{abstract}

Key Words: immigrant women, immigrant families, settlement, roles of immigrant women, women's support 


\section{Acknowledgements}

First I would like to express my gratitude to my supervisor, Dr. Mehrunnisa Ahmad Ali, for her useful comments and support. I would also like to acknowledge Dr. Harald Bauder as the second reader of this MRP for his valuable comments on this paper.

This MRP was based on the data of the project "Integration Trajectories of Immigrant Families" managed by the Ryerson Centre for Immigration and Settlement and funded by Social Sciences and Humanities Research Council of Canada. I was blessed to have an access to that data and would like to thank all the individuals and organizations who was involved and worked on this project.

Finally, I would like to thank my family and friends for their continuous support and encouragement through my studies and the process of writing this paper. 


\section{Table of Contents}

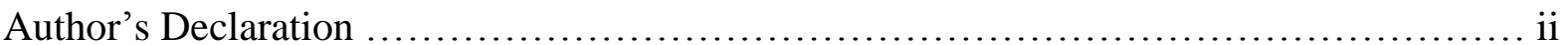

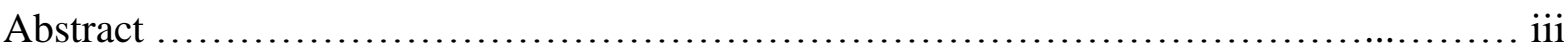

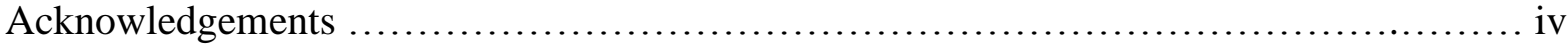

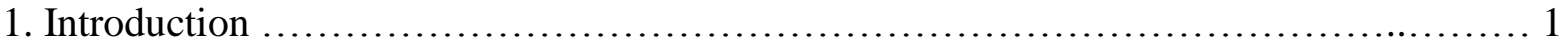

2. Theoretical framework and literature review ....................................... 4

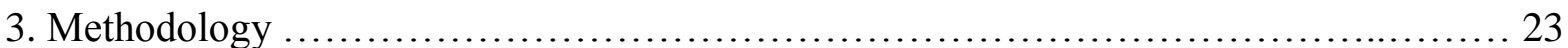

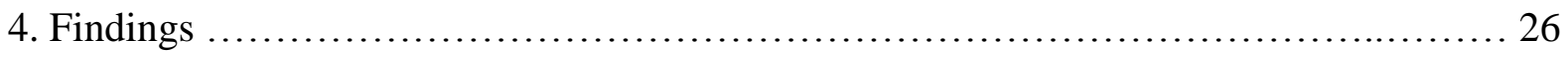

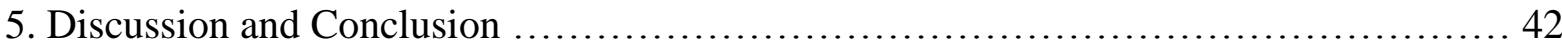

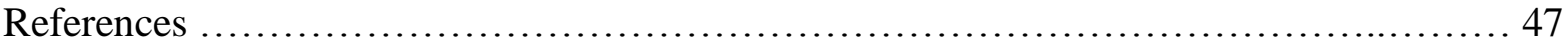




\section{Introduction}

Globalization, better economic conditions and liberal immigration policies in the developed countries encouraged skilled migration from developing countries in the last decade of the twentieth century (Lindsay \& Findlay, 2001). Despite the fact that the majority of main applicants under the economic category were men, women constituted $55.3 \%$ of immigrants who were admitted as spouses and dependants under the economic class to Canada in 2013 (Hudon, 2015). Overall, 52\% of immigrants under economic, family and refugee classes were female (Hudon, 2015). The majority of immigrant women in Canada $(81 \%)$ live in the 'census family' that includes a married or common-law couple, with or no children, or a single parent with at least one child living in the same household (Hudon, 2015). In the country of destination, women perform their traditional and newly-assumed family roles and responsibilities (Nichols \& Tyyska, 2015), through which they facilitate settlement of their family members. However, migration scholars have focused mainly on employment problems and barriers which immigrants face in the country of destination, while feminist scholars advocate for rights of the dominant white middle class women and neglect the presence of racialized immigrant women in the local societies (Jamarani, 2012). There has not been enough attention to the settlement experiences of newcomer families and the role of women in that process.

The research problem of this paper is immigrant women's invisible contribution to their families' settlement. The non-recognition of women's roles in their families' settlement by government and professional organizations results in ineffective settlement programs, poor settlement experience of families and their slow integration into the Canadian community. The economic costs of the weak integration of immigrants are a waste of human capital and increase in the number of immigrants living in poverty and dependents on 
government-provided welfare (Biles, Burstein, \& Frideres, 2008). In this paper I will analyze narratives of immigrant families landed in Canada, study their settlement experience and needs, and examine the roles of women in this process. Better understanding of how women contribute to their families' settlement will help to determine the ways how that support could be facilitated by the settlement organizations to accelerate that process and avoid delaying it for women.

Women and men are not equally represented as main applicants in the immigration process in Canada. In patriarchal immigrant families, women's roles of mothers and household keepers, whose careers are interrupted by child birth and care, make them less likely to be the principal applicants under economic class immigration programs (Government of Canada, 2016). In 2015, women constituted only $37 \%$ of the total number of principal applicant skilled workers with a slow increase of 7\% from 2006 (Government of Canada, 2016).

Many researchers study the external factors that help immigrants settle in Canada, such as settlement services and bridging programs. However, there is little known about how families, and in particular women facilitate this process. The neo-liberal focus on individuals rather than families (Brown, 2003), and the perception that the skilled workers can integrate successfully into the receiving society simply because they can enter the labour market of Canada (Root, Gates-Gasse, Shields, \& Bauder, 2014) needs to be questioned. Policies based on this assumption have resulted in the decrease of public funding for the settlement and social services, and have made immigrants struggle more and longer. We need to learn more about how immigrant women who often stay at home to take care of children, do physical work in the household, and take survival jobs to provide the men in their families opportunities to improve their credentials or learn official language skills, help to mitigate the 
effects of such policies. By 2031, the number of immigrant women will increase to 5.8 million and make up 27.4\% of Canada's total female population (Hudon, 2015). Given this growing number it is important to understand how women support their family members' settlement. 


\section{Theoretical framework and literature review}

In this section I will discuss two theoretical frameworks that provide the lens through which I will analyze the settlement experiences of immigrant women: neoliberalism and feminism. The neoliberal theory explains why immigration and settlement policies in Canada and other Western countries ignore the role of women and families in the settlement of immigrants. Then I will examine some feminist theories and discuss why they do not fully address the problems of immigrant women.

Neoliberalism. In the modern world, migration is one of the main sources of the labour force supply and a tool to solve demographic problems of immigrant receiving countries. National prosperity depends on innovations produced by a skilled labour force, which explains many nation states' interest in highly skilled migration (Gabriel, 2004). Efficiently utilized skilled human capital creates a comparative advantage for receiving countries and enables them to compete in the global market. The neoliberal immigration policy of Canada is market-oriented and focused on attracting skilled workers because their previous education, skills and working experience produce economic benefits. Immigrants' labour and their taxes also help to meet shortfalls in services in stagnant or declining populations.

Neoliberalism as an economic model became popular in the early 1980s and replaced the Keynesian model of "controlled capitalism" imposed in the post-Great Depression period (Steger \& Roy, 2010, p.7). The government-regulated economy could not deal with the oil crises of the 1970s and other economic problems such as low economic growth rates and high inflation (Steger \& Roy, 2010). Therefore, the neoliberal model of the self-regulating market and international free trade was believed to overcome economic stagnation (Steger \& Roy, 2010). 
Nation states have restricted immigration of foreign nationals to preserve welfare and security of their citizens. Throughout history, Canadian immigration policies have reflected interests of various groups such as employers, who viewed immigrants as workers, investors and taxpayers (Kelley \& Trebilcock, 2010). First Canadian immigration policies were highly restrictive and selective based on race, gender and ideology (Kelley \& Trebilcock, 2010). That practice stopped in the post Second World War period when the immigration policy of Canada became more liberal due to economic prosperity, labour shortages and increasing support of the public.

The Canadian immigration policies have been guided by "the neo-liberal concepts of self-sufficiency and personal responsibility" of immigrants and their families (Shapaizman, 2010, p. 20). The individual-oriented approach of "flexible immigrants" proposed that they would easily adapt to the new environment including the domestic labour market (Root et al., 2014, p.4) due to their foreign-obtained skills, education and qualifications (Shapaizman, 2010).

Neo-liberal policy makers see individuals as "entrepreneurial actors in every sphere of life" with the "self-care" ability and self-responsibility (Brown, 2003). That individual approach differed from that of the previous immigration policy which had focused on "nation-building and longer-term integration goals" (Shields, 2004, as cited in Root et al., 2014, p.4). Immigrants have been viewed apart from their families, and thus, the problems of the latter have been ignored (Brown, 2003). Therefore, families stopped being the main focus of settlement policies, the public support for settlement services was reduced, and that resulted in slower labour market and overall settlement and integration of newcomers (Root et al., 2014). 
Neoliberal globalization has been "driving white working-class women out of the home and into the labor force," which decreased employment opportunities for racialized immigrant women and kept many of them in low-paid jobs (Toro-Morn, Guevarra, \& FloresGonzález, 2013). Women's contribution to the well-being and settlement of their families is not taken into account by neoliberal scholars. Neoliberal states oriented on economic benefits do not see formally non-employed or employed in low-qualified jobs immigrant women as efficient economic actors due to their insignificant economic contributions to the national market economy.

Feminist framework. Immigrant women have more barriers to migration than men due to their traditional family gender roles (Hondagneu-Sotelo, 2000). That statement contradicts to the claims of demographic scholars on feminization of migration, according to which more women migrate across the world in 2015 comparing to 1960 (Donato \& Gabaccia, 2016). However, despite the double increase in the number of migrant women, their share in the international migration increased only by 1.4 per cent for the last 55 years (Donato \& Gabaccia, 2016).

The lives of women had been neglected in oral history of Canada (Sangster, 2011). Studying women's past could help to understand their social and cultural challenges and experiences (Sangster, 2011). Therefore, it is important to study the immigration and settlement experiences of women so that they could have equal settlement opportunities and access to public services that will improve their settlement in the country of destination. There are many Canadian feminist works studying women and their settlement experience described in the literature review. I also examined the works of some U.S. and Australian scholars which could also be helpful in explaining the experiences of immigrant women in Canada. 
Hondagneu-Sotelo (2000) acknowledges that women in the United States have more egalitarian opportunities since the late twentieth century in other areas with small changes in the labour market. The feminist movements for civil rights led to more shelters for abused women, laws for women's reproductive right, against domestic violence and discrimination (Hondagneu-Sotelo, 2000). However, despite the political and media slogans that immigrant rights were civil rights in the United States in the 1990s, the anti-immigrant sentiment and xenophobia proved to be persistent. Various labour, religious and ethnic communities defended the equal rights of immigrants in the United States to stop discrimination against immigrants (Hondagneu-Sotelo, 2000). However, feminist movements did little to advocate for the rights and needs of female immigrants because the latter did not have a powerful voice in the society due to their socio-economic position there (Hondagneu-Sotelo, 2000). Hondagneu-Sotelo (2000) argues that immigration and feminist scholars focused mainly on problems of undocumented immigrants and permanent residency immigration laws. The major research focus of feminist studies was on women's social and cultural issues of immigration, their identity formation, citizenship and transnational connections (HondagneuSotelo, 2000).

The scholars discussed "how domestic roles anchor women and how public-sphere ties facilitate men's migration" (Hondagneu-Sotelo, 2000, p.114). Feminist scholars then shifted their research attention to the gendered relations in households before and after migration and how migration affects gender inequality (Hondagneu-Sotelo, 2000).

Challenges in the receiving societies may cause conflicts, separations and negotiations among spouses, whose contribution to their families' settlement become equal through the development of social network and employment (Hondagneu-Sotelo, 2000). Espiritu (1999) and Menjivar (1999) stated that power relations and gender equality in households changed 
due to women's employment (as cited in Hondagneu-Sotelo, 2000). In the 2000s, the feminist research attention shifted to studying gender as "a constitutive element of immigration" in various fields such as cultural, economic, social and political spheres (Hondagneu-Sotelo, 2000, p.117). The main critique of that feminist focus was ignorance of the immigration policies and anti-immigrant sentiment (Hondagneu-Sotelo, 2000).

Nowadays, changing gender roles of family women with the process of immigration are paid more but still not enough attention by feminist scholars (Bonifacio, 2012). Salem (2012) argued that settlement support of the host societies encourages transformation of status of immigrant women in their families and community. Jamarani (2012) wrote about how Iraninan immigrant women negotiated gender roles and identity between cultures of Iran and Australia. There are many factors that influence emancipation and empowerment of women from traditional patriarchal societies, such as ties to the community and the patriarchal family (Jamarani, 2012). Australian feminist literature mainly focuses on the rights of white women of the middle class and ignores the status of racialized women living in Australia (Jamarani, 2012). The reason for that limited scope is explained by Kilic (1997) as the existing perception of the "universal gender experience defined by the terms of experience of a particular group of women" (as cited in Jamarani, 2012). Racialized immigrant women should be studied more within migration and feminist framework. Walby (1990) named that kind of expropriation of women's labour as private patriarchy. The scholar described four main approaches to structure gender relations: radical feminism, liberal feminism, Marxist feminism and dual -system theory. Radical feminists define patriarchy as a system under which "men as a group dominate women as a group and are the main beneficiaries of the subordination of women" (Walby, 1990, p.3). Marxist feminists view patriarchy through social class lenses where women benefit the family by 
performing household work which is divided unequally among family members of different sexes (Walby, 1990). Therefore, women provide their cheap labour for maintenance by men. Liberal feminists focused on studying unequal employment and education opportunities for women (Walby, 1990). Dual systems theory states that Marxist and radical feminist theories are important to analyze gender inequality in "capitalist-patriarchal society" (Walby, 1990). Another type of patriarchy is public, in which women are paid lower wages than men and work in different occupations due to gender inequality (Walby, 1990). When a woman makes a decision to join the labour market, she is restrained by her family and household duties determined by their cultures (Walby, 1990).

The gendered immigration practices with men as principal applicants and main migration actors while women are dependents also reflected traditional gender roles in patriarchal societies (Knapp, Muller, \& Quiros, 2009). Power relations within the family influence migration decisions such as who manages to migrate and to which countries and also determine family roles and duties of men and women after landing in the country of destination (Boyd \& Grieco, 2003). In the patriarchal power structure of families in most parts of the world, particularly in countries from where immigrants to Canada come, it is assumed that interests of men coincide with those of their families and are prioritized due to men's socio-economic power of breadwinners (Boyd \& Grieco, 2003). Women are often excluded from economic participation and perform traditional duties of taking care of their families and housekeeping (Boyd \& Grieco, 2003).

It is important to define criteria of successful settlement in order to determine settlement goals and study how immigrant families achieved them. According to the Canadian Council for Refugees, there are four spheres of settlement and integration: economic, social, cultural and political (Jimeno, Martinovic, Gauthier, Bouchard, \& 
Urquhart, 2010). Successful settlement includes such parameters as financial independence, developed social networks, adaptation to the local lifestyle, redefining cultural identity, and active political participation and citizenship (Jimeno et al. 2010). Ng-See-Quan (2013) calls similar factors of "affordable childcare, housing, social supports and networks, education, and employment opportunities" (p. 4) as social components of health. The knowledge of Canada's official language is the key requirement for that.

The literature review demonstrated that there are various settlement services provided by immigrant-serving organizations to assist newcomers in overcoming multiple challenges to their settlement in Canada. However, some of those services are not accessible to immigrant families due to language and cultural barriers, immigrants' financial and family needs. This review also showed how immigrant women help their families to settle in Canada by providing financial, physical, social and emotional support.

\section{Financial support.}

The majority of immigrants (61.8\%) assume employment as a major need (Ali, Kobayashi, Cliff-Jungling, Ochocka, Lomotey, Araujo, \& Kljujic, 2012), vital for their wellbeing and the settlement process. The higher unemployment rate among immigrants who settled in Canada 5 years ago or less (10.9\%), compared to 5.9 per cent of the unemployed born in Canada, demonstrates that newcomers face huge employment barriers (StatCan, 2016). Skilled immigrants often have to improve their language and professional skills, take bridging programs and develop social networks to find employment in the desired field and position. The path to skilled employment requires time, efforts and support from family members, especially from a spouse, who is able to work and support the family financially.

The perception that earnings of a working adult are enough for an economic wellbeing of the whole family does not always work for immigrant families in Canada (Ali, 
Corson, \& Frankel, 2009). Newcomer families often experience transformation of traditional roles of men as single breadwinners and women as housewives (Nichols \& Tyyska, 2015). Therefore, in many immigrant families both parents have to work to pay for the family needs. Immigrant women join the labour force to help their families to survive in the new environment. They are believed to find better employment opportunities than men, and are often the first in the family who get jobs (Nichols \& Tyyska, 2015).

In the period from 2001 to 2006, the labour force participation rate of newcomer women increased by $16.8 \%$ which is more than two times higher than the rate for Canadianborn women (7.4\%) (Chui, 2011). There are several factors explaining why immigrant women decide to enter the labour market. First, more economically active women were admitted to Canada as principal applicants under the economic immigrant class (Hudon, 2015). The rate increased from 30\% in 2004 to $40.9 \%$ in 2013 (Hudon, 2015). Second, the increasing numbers of married immigrant women joined the labour force for the first time (Morissette \& Galarneau, 2016). In the period from 2010 to 2014, the labour market participation rate of married visible minority women aged 25-54 was higher in the destination countries $(76 \%)$ than in the source countries $(60 \%)$, which demonstrates that women started their first employment in Canada to meet the financial needs of their families (Morissette \& Galarneau, 2016).

Overall, recent immigrant women were more likely (31.1\%) to work part-time than other immigrant women (26.6\%) and Canadian-born women (30\%) (Hudon, 2015). I therefore assume that immigrant women are more likely to work part-time because it allows them to take care of their families.

There have been various programs and workshops organized at municipal, provincial, territorial and federal levels to solve employment problems of skilled immigrants (Ontario 
Canada, 2016). Provincial bridge training programs include activities aimed to engage employers in immigrants' economic integration such as Ontario’s online training infrastructure, the mentoring partnership to help newcomers to build professional network and receive information about the labour market specifics, internships and seminars (Ontario Canada, 2016). However, not all immigrants and especially women are able to participate in those programs because they have to perform family duties and earn income to support their families, and thus, they often accept low-level jobs to survive (Raghuram \& Kofman, 2004). More women (19\%) than men (13\%) indicate poor knowledge of English or French as a key barrier to the Canadian labour market (Hudon, 2015). The poor knowledge of one of the official languages makes the integration process longer, which results in devalued human capital of skilled immigrants (Raghuram \& Kofman, 2004). Raghuram and Kofman (2004) described the case of foreign-educated female nurses, who sacrificed their skilled employment for their families' financial well-being. Their educational and work experience credentials were not recognized in Canada and they should take nursing exams to be certified in this occupation (Raghuram \& Kofman, 2004). However, they had poor knowledge of the official language and had to first improve their language skills to take the nursing exams (Raghuram \& Kofman, 2004). The foreign-educated nurses could not afford to attend language schools because they had to earn income to support their families, and thus they took jobs in other fields to survive (Raghuram \& Kofman, 2004). The paradox of this case is that there is a shortage of nurses in Canada despite a great number of unemployed foreigntrained nurses. The lack of the proper official language skills results in presumably temporary deskilling of foreign-educated workers, which then turns into permanent deskilling of immigrants due to the language and skilled employment barriers, and the lack of opportunities to go back to their occupations later (Raghuram \& Kofman, 2004). Low-level 
employment of immigrant women contributes to settlement of their families but prevents them from preparing for and subsequently acquiring skilled jobs, results in their deskilling and delays of their own successful settlement.

\section{Physical support: childcare and household duties.}

Many recent immigrant women stay at home to take care of their family members (Ng-See-Quan, 2013). The traditional women's role of household keepers and mothers prevent them from economic integration because they sacrifice their own prospects for meaningful employment for the well-being of their families by not taking language classes and professional trainings (Tastsoglou \& Preston, 2005, p.52). Traditionally they spend more time on primary care of children than men (Nichols \& Tyyska, 2015). Unfortunately, many immigrant housewives continue to live in economic and social isolation (Ng-See-Quan, 2013). Immigrant women's household work and care of family members allow the latter to spend more time and other resources on their settlement by taking language courses and professional training and focus on seeking better employment opportunities.

Immigrant wives, who are married or live in common-law relationships are less likely to join the labour market (76\%) than Canadian-born wives (88\%) due to various socioeconomic characteristics including the family size (Morissette \& Galarneau, 2016). The average newcomer family's size of four persons is bigger than of their Canadian-born counterparts, and caring of family members prevents immigrant wives from joining the labour market (Morissette \& Galarneau, 2016). More immigrants (13\%) live in the extended families in Canada comparing to the Canadian-born residents (6\%), which shows that the extended family structure in the countries of origin continue to work in the destination countries too (Government of Canada, 2005) Married women stay at home to do household work, look after children and care for the rest of their families due to the strong ideology of 
patriarchy (Bradbury, 2001). Overall, more immigrants than Canadian-born residents of 15 years old and over provide unpaid care of children, $40 \%$ and $28 \%$ respectively; and of elders, $16 \%$ and $14 \%$ respectively (Government of Canada, 2005). More immigrant women than immigrant men care of their family members, comparatively the number of women providing unpaid primary care of children and elders exceeds that of men by $27 \%$ and $36.5 \%$ respectively (Government of Canada, 2005).

The absence of the national child care program in Canada and thus, the lack of federal funding of child care and limited capacities of provincial governments make child care services accessible only to the minority of the population in all provinces except Quebec (Friendly, 2014). Child care fees in Toronto reached \$1,676 per month in 2014, which is 11 times higher than in Quebec (\$152 per month) (Friendly, 2014). Additionally, the accessibility to child care is getting lower also due to increase in the number of children aged from 0 to 4 years old (Friendly, 2014). A lack of child care services constraints immigrant women's settlement because they prioritize their husbands' settlement and stay at home to take care of their children and do household duties.

Mothering as social and personal work is often not recognized as work and receives little help from husbands and other family members (Roseberg, 2001). Gender and class, patriarchy and capitalism explain sexual division of labour in industries and households in Canada and other countries (Bradbury, 2001). Parenting creates gender differences and assigns more responsibilities of primary caregivers to mothers, and breadwinners to fathers (Fox, 2001). Men determine their role of a father as a "mother's helper and baby's playmate" (Fox, 2001, p.289). In the origin societies, women's parenting and household duties were shared by their extended families, represented by multigenerational family members who provided various kinds of support such as raising children, housekeeping and sharing 
economic expenses (Chen, 2011). The Canadian immigration policy of including only the nuclear family members into the application for permanent residency breaks those socioeconomic relationships of extended family members. Multiple family responsibilities have to be redistributed among their nuclear family members, which increases the burden of family duties per person, and for the most part of women.

Knowledge of one of the Canadian official languages is vital for integration into the receiving society (Kilbride \& Ali, 2010). Far less immigrant women than men are proficient in either English or French before coming to Canada (Kilbride, K.M., \& Ali). Immigrant women often have no opportunities to take language classes because they should perform family duties as mothers and wives, and that increases their social isolation and results in their poor settlement (Frisken \& Wallace, 2000). The Language Instruction for Newcomers in Canada (LINC) program funded by the Government of Canada is available for permanent residents at no cost (Government of Canada, 2017). The major barrier for immigrant mothers to attend the LINC classes is lack and limitations of available child care services at language centres during the class hours (Kilbride \& Ali, 2010). Those centres set the minimum age or the quantity limits for the children from one family, or establish a fee for their childcare services (Kilbride \& Ali, 2010). Moreover, some agencies consider that those permanent residents who had lived in Canada more than three years to be ineligible for the LINC program (Kilbride \& Ali, 2010).

Those limitations and extra expenses create additional barriers towards settlement for immigrant women with children. Therefore, women delay their integration into the receiving society until their children grow up. Frisken and Wallace (2001) told the story of a skilled newcomer woman who could not apply for citizenship and get skilled employment in Canada due to her poor English language skills. She gave birth to a child right after landing in 
Canada, then took care of the baby, performed household duties, lived an isolated life and consequently could not learn English (Frisken \& Wallace, 2001, as cited in Ng-See-Quan, 2013). Besides English, other obstacles to employment for immigrant women are their age and lack of recent work experience (Ng-See-Quan, 2013).

Women perform household duties and care of children and elders, and hence, they take this burden from their spouses and other family members, allowing the latter to settle in the host society. The costs of women's physical support of the families are their social isolation and deskilling, which should not take place because settlement of women would contribute to successful settlement outcomes in the long-term not only of those women but also of their families (Ng-See-Quan, 2013).

\section{Social support.}

Stewart and Lagille (2000, as cited in Simich, Beiser, Stewart, Mwakarimba, 2005, p. 259) defined social support as "interactions with family members, friends, peers and ... professionals that communicate information, esteem, practical, or emotional help." Simich (2005) states that newcomers experience social isolation right after landing in the host country because they cannot receive social support to the extent they used to get in their origin societies, and need to find new sources of that. Public services providers admit that many immigrants cannot get government funded support service because of lack of public funding, geographical reasons and other service restrictions (Simich, 2005). Therefore, families, co-ethnics, neighbours and friends sometimes are the only sources of social support for immigrants (Simich at al., 2005).

Misallocation of human capital is an important economic problem of the host society because it brings low returns on "investments in immigrant selection and integration" (Biles, Burstein, \& Frideres, 2008, p.7). Employment is a vital goal for immigrants because it 
provides them with the financial security. However, they lack social networks in Canada, which "may shape employment outcomes and processes, namely, by conveying resources and providing signals to others" (Castilla, Lan, \& Rissing, 2013, p.999). Those social ties allow people to use their resources such as information and influence to refer and support each other, and thus promote employment (Castilla et al., 2013). Social networks of the organization's employees are often used as sources to lower the costs of recruiting (Society for Human Resource Management, 2011, as cited in Castilla et al., 2013). Higher and betterpaid positions are attainable for those candidates who have "higher-status personal contacts" and hence, are not attainable for immigrants (Lin et al., 1981; Lin, 1999, as cited in Castilla et al., 2013).

Families with or without children may receive support from settlement services in forms of workshops, which provide basic information about health services, parenting in Canada, education system and available resources (COSTI, n.d.). However, those workshops are organized in big cities and provide only occasional support, while families need permanent consulting services to solve current settlement problems regarding their children, and learn more about Western parenting practices, like the need in structured early childhood development (Jimeno et al., 2010). Many settlement family service providers do not know about the various needs of immigrant parents (Jimeno et al., 2010), which prevents them from developing effective solutions. Therefore, immigrants find that social support from their family members or other immigrants.

As usual mostly women represent parenting functions at schools by interacting with the community, the school administration and other parents (Nichols \& Tyyska, 2015). They try to assist children in understanding the new educational system and school requirements, and doing home assignments (Nichols \& Tyyska, 2015). However, one of the barriers for 
"effective communication" between teachers and immigrant parents is the immigrants" poor knowledge of English or French, and institutions' culture, which restricts them from full participation in their children's school life (Ali, 2015, p. 282). Good parent-teacher relations are also complicated by their false expectations of each other (Ali, 2015).

There are various ways how immigrant families might be supported in Canada. The experience of integrating immigrants into the host community might be adopted from Germany, France, the USA, Denmark, Spain, New Zealand and England, which offer integration courses designed for immigrant women and children (Shields et al., 2016). Approximately 960 lessons offered by the Federal Office for Migration and Refugees (2015) in Germany and taught by women were developed to improve not only women's knowledge of the official language but also to inform them about the local education system, create opportunities to establish women's social network.

The interaction and social networks of immigrant parents and their children with school institutions and Canadian parents might be facilitated through sports programs targeting immigrant children and implemented in Australia, Germany, Belgium, the Netherlands and Denmark (Shields et al., 2016). Sport matches create good opportunities for immigrant parents too because they may build social networks and social capital (Shields et al., 2016). The appropriate interventions of the professionals may contribute to socialization of immigrant families, by organizing a play group for newcomer children and encouraging parents to take language courses (Colbert, 2012). Settlement family programs could help working-age family members in their efforts to pursue better employment opportunities, and thus, decrease the number of immigrant families living in poverty and of newcomers who return to their countries of origin due to their poor settlement in Canada, low income and declining living conditions (Biles, Burstein, \& Frideres, 2008). 
Robert and Gilkinson (2012) suggested that social isolation and thus some emotional problems of immigrants could be prevented by encouraging them to participate in organizations and groups. Recent immigrant women (55\%) and immigrant women who landed more than five years ago $(61 \%)$ are less likely to be members of organizations and associations than Canadian-born women (67\%) (Hudon, 2015). Joining organizations could help to facilitate their social and economic integration and achieve their own and their families' integration into economic, social, cultural and political life (Jimeno et al., 2010).

\section{Emotional support.}

Emotional support is an essential need for immigrants struggling for their economic and social well-being. The main post-migration stressors are "unemployment, separation from family, discrimination and prejudice, language barriers and lack of social support" (Robert \& Gilkinson, 2012, p.1). Balancing origin and destination cultures is the best model of behaviour for immigrant families. However, newcomers need time to learn the appropriate behavioral norms practiced in Canada to integrate into the domestic community (Girard \& Bauder, 2007, p. 39). The constant stress because of lower wages, lower living conditions comparing to the previous pre-arrival socio-economic status, barriers to skilled employment and frustration often cause psychological problems and depression of adults (Uzair, 2014).

Another source of mental and emotional problems is health issues of family members (Stewart, Makwarimba, Beiser, Neufeld, Simich, \& Spitzer, 2008). Settlement becomes the second priority for parents when their children have health problems (Stewart et al., 2008). Newcomers are afraid to get sick because their jobs or the government do not cover the extended health services (Stewart et al., 2008).

During the first 10 years in Canada, approximately $30 \%$ of immigrant families live in poverty (Public Health Agency of Canada, PHAC, 2006). Roughly 29\% of newcomers 
experience emotional problems, and $16 \%$ have a high level of stress during the first four years in Canada. Women, refugees, immigrants with low income and visible minorities are more likely to report emotional problems and stress (Robert \& Gilkinson, 2012). The latter can cause various mental and physical diseases, affecting family and personal relationship (Public Health Agency of Canada, PHAC, 2006). The economic consequences of stress are "lost productivity and disability claims" (PHAC, 2006). Therefore, addressing mental health problems among immigrants early in life helps to prevent mental disorders and promote their economic and social integration.

Immigrants are more likely to seek emotional support from their families and friends living in their countries of destination or left in the source countries, settlement counselors and local ethnic communities, rather than from medical professionals (Robert and Gilkinson, 2012). Language barriers, unfamiliarity with the local medical system, and absence of culturally sensitive medical services are the main obstacles to the use of professional services among immigrants (Robert and Gilkinson, 2012). Therefore, the nuclear family members, and particularly women are the main and usually the first source of emotional support to spouses and children due to their roles of mothers and wives.

In 2011, almost one fifth (19.2\%) of recent immigrants to Canada were children aged 14 and under (Colbert, 2012). It is believed that children of 14 years old and younger adapt to the new environment easier but Colbert (2012) argues that young children also face multiple challenges in the country of arrival. Newcomer children experience emotional stress complicated by their long "development as individuals" (Colbert, 2012, p.302). Families and friends are one of the main sources of wellbeing of children and their support helps children to overcome emotional distress in the process of settlement in the new society (Lawrence, Collard \& Kaplan, 2013). Mental health of children and parents are interconnected (Lawrence 
et al., 2013). Immigrant children's acculturation attitudes are consistent with their parents' attitudes, meaning that children follow the role models of their parents and are open to adapt if their parents are open too (Aycan \& Kanungo, 1998). Therefore, if immigrant parents experience emotional problems, that complicates children settlement.

However, immigrant parents often complain about culturally incompetent school support, when school administrators decide in which language instruction and which services should be provided to young newcomers on an ad-hoc basis (Jimeno et al., 2010). The school problems of immigrant children could be the consequence of pre-migration and postmigration problems of a child and the whole family. Involvement of parents in solving behavioural and academic problems of their children can help to identify the true causes, find best solutions and have a far-reaching effect of solving some other personal and settlement problems of the family (Colbert, 2012). Colbert (2012) discussed the settlement case of an eight-year old refugee child, who landed four years ago with his mother. The school administration referred him to psychiatric assessment for being socially isolated and not progressing in his studies. The author concludes that this boy's ability to progress in school depends on his mother's "ability to provide effective support" to her son regularly (Colbert, 2012, p.302).

This literature review explains how immigrant women encourage their family members in their settlement by providing financial, physical, social and emotional support which is in most cases invisible to public services providers. Gender roles in many immigrant families transform due to the needs of those families: many newcomer women join the labour market to support their families in the host country for the first time in their lives while continuing to perform traditional gender duties of mothers and wives assigned to them in their home patriarchal societies. Inaccessible child care and lack of the extended family's 
support in the host country makes women sacrifice their professional careers and settlement for the sake of other family members, particularly husbands, who may spend more time and apply more efforts to settle successfully. Women are often the only source of emotional and social support to their family members in the receiving country; they develop social networks through schools for their families. Families play an important role for the settlement of their members with the significant but often invisible contribution of women. 


\section{Methodology}

This study was based on the secondary data collected by the research team of the collaborative research project "Integration Trajectories of Immigrant Families" managed by the Ryerson Centre for Immigration and Settlement and funded by Social Sciences and Humanities Research Council of Canada. The interviews provided life stories of immigrant families explaining how and why they made the decision to immigrate to Canada, their settlement experiences, their needs and how they were met, and how their family relations and roles changed during the settlement.

\section{The Research question}

The aim of this paper is to study the following research question: How do women support their families' settlement?

\section{Data collection}

The participants for the project "Integration Trajectories of Immigrant Families" were recruited through settlement organizations located in the Greater Toronto Area (GTA). The criteria for participants were economic class immigrants, who had settled in the GTA 5-10 years ago, and were able to communicate in English (Valade, 2017). The respondents represented 23 families including 18 women and 10 men, 34-63 year old, 4 teenagers. The interviews were semi-structured and included 2 interviews of each respondent or a family taken during fall 2014 - winter 2015. At the first interview, the narrative overview was recorded, and participants drew a family sociogram to indicate people they considered to be their families. At the second interview, participants explained family relationships indicated in the sociogram, and discussed policy issues (Valade, 2017). They also described who of their family members and how contributed to their settlement in Canada. Some participants discussed the roles of women in this process. 


\section{Data analysis}

All interviews were tape-recorded and later transcribed. Therefore, I analyzed transcriptions of respondents to study the research problem of this paper: invisible contribution of women to their families' settlement. I excluded transcriptions of 3 respondents from my data analysis because the respondents were single and remained so after immigration to Canada, and thus their settlement experience did not contribute to my study. Therefore, I analyzed interviews of participants from 20 families. Altogether, the number of participants was 25 because there were 3 interview sessions with more than one participant from the same family. They were a mother with three children, a mother with a child, and a couple.

I analyzed the data regarding the women's family roles and responsibilities contributing to their family's settlement. I developed my own codes to organize the data into four themes: financial, physical, social and emotional types of support. I did comparative analysis of family needs and family roles of immigrants both men and women before and after immigrating to Canada in order to see the transformation of family roles, relations and behaviours due to settlement needs. I discussed the data in four subsections named in accordance to the type of support women provided to their families' settlement.

\section{Limitations of the Study}

My research was based on the secondary data acquired from the project "Integration Trajectories of Immigrant Families," and thus the respondent selection criteria, the interview format and questions were designed by the project research team to study their research question of families' roles in immigration and settlement. The interview questions and the sociogram were aimed to explore whom the respondents considered to be their families and how they supported the interviewees in their decision to immigrate to Canada and during 
their settlement period. Women were among those family members and contributed to their families' settlement but they were not of the main focus of the larger study. I analyzed the narratives with the aim to extract information for my research interest because not all interview questions and answers contributed to my studies. My findings are not generalizable. However, they can help raise important questions that can guide future studies. 


\section{Findings}

The literature review helped to categorize women's support of their families' settlement into four groups: financial, social, emotional and physical support. The research project data was analyzed to find out which of those kinds of support was provided by immigrant women and its significance in settlement of their families. For the purpose of maintaining respondent confidentiality their names were replaced with pseudonyms.

Certainly family members had supported each other before they moved to Canada but respondents emphasized the importance family support in their immigration and settlement experience in general.

Samia: In my situation my family is very supportive. They help us emotionally.

Paulette: The family? Absolutely, it is absolutely important to the settlement process. One, it provides that support because moving to Canada, coming up against all the challenges, I mean it is a new environment, it is a new culture, it is new people, I mean people with different perspectives.... That, the need for family is very important, especially when it is cold, it is dark...

Fatima: Yeah, family, families are important because when they came here, they can support each other. They know each other. They are not one individual, when they are an individual, they can get depressed. They do not have support. They need to support each other.

The respondents agreed that it would be more difficult to settle and live in Canada without support from their family members and especially without support from their wives and mothers, who encouraged them to take further steps in their settlement. Due to the common challenges in the new environment both husbands and wives confirm they became closer:

Jon: Yes, someone in my company, he lost his wife one year ago. He is very suffering from loss. He cannot go outside at night. And compared to that, I am very happy. Because if there is no support from my family, I cannot do anything.

Amit: Like when I was out of job for the last, sometime, due to my parent illness, so my wife supported very well, my daughter supported me and my son. 
Lee: So we went through the hardships together, then after ... I feel my family more united, closer.

\section{Financial support}

Both spouses in the surveyed families had post-secondary education. They immigrated to Canada under the Federal Skilled Worker Program but most of them could not get skilled employment and had to take low-paid jobs which did not demand their professional skills and knowledge to survive in Canada. Immigrant women often become breadwinners in their families in Canada (Nichols \& Tyyska, 2015). Olga immigrated with two teenage children. She had to get the license to work in her field in Canada but it was difficult for her as a newcomer to get references and find paid internship. She could not afford to have unpaid internship and invest in her career right after she came to Canada because she had two children depending on her financially. Therefore, Olga like another woman Dasha sacrificed her previous professional career and worked in another field as the only breadwinner in the family.

Olga: I saw the situation very risky because I had to support my kids. I have to work. So I sacrificed-- I think what I did was to sacrifice myself at some point to support them [children]. And that is how I take this time ... So, and there are many, many opportunities here to work, but it is also painful. All the years and money I had put in my ... education.

Dasha: Well he was always-- As I said, I used to do stuff that I liked. I never had to work for money. I did not make money, but not because I was the breader. In Canada it was completely different. I did not want to lose my job, what would happen? My husband is not ready yet, three kids. I understand there is welfare but still, that is not the option that we wanted.

Fatima, a newcomer woman, also had to give up her dream to return to her previous career because she worked hard and was the main breadwinner in her family, so that she did 
not have time to improve her English skills and take all required courses in her field. She prioritized her family's wellbeing to her professional settlement in her previous field.

Fatima: I still like to get my job in my field. I always need to improve my English. Now I told you that I am the manager at my store. I do not have time to take courses for social services at [institution name] College. I do not have time to take many course. I got like one course or two course each semester. This semester I did not get any because I am very busy in my job]. If I had some financial support, I would prefer to study but I do not have financial support. I have to work and support my family and everything, like insurance, like mortgage, like everything.

In Canada, both immigrant parents have to work to earn enough money to support their family (Ali, Corson, \& Frankel, 2009). Women combine their traditional roles as mothers and housekeepers with that of a breadwinner. A wife of one of the respondents Tarik worked from home before giving birth to the fourth child to support her husband and share breadwinning duty.

Tarik: So that call, those call, you know, order-taker, they are not sitting anywhere. My wife, she is one of those. She -- What does the software in the computer. Okay. So today she got a schedule and according to that schedule on weekends it is very busy. She can work according to her situation. Nowadays she is not working that much. Last year she worked really good. So she did not like she is zero [meaning as if she was useless]... That is some sort of active. She earned money last year because it was -- you are at home.

Immigrant wives often had to take low-paid jobs to support financially their families while their husbands were studying and investing in their prospects as skilled workers. The following passages demonstrate that spouses saw it was more efficient when one of them worked and, let the other invest making a career. However, it was mainly women who prioritized their husbands' studies and professional settlement while delaying their own. Nari said that she supported her spouse's studies by working and taking care of their two children born in Canada, and as a result she could take English classes only after their children grew up a little bit. 
Nari: Because my husband study at college. And then, I work part-time. Restaurant, ... Yes. And then, work full time. I had a full time job, cleaning. ... : Yeah. One person he just study [sic], and one person working [sic], and then, one person is working, and maybe I am studying.

Fatima: Everything, even financial. One person can work, another can stay at home and support their children. One person can work and another person can study. It is important.

Dawit: I was trying to network. Well, I submitted my dissertation around the beginning of June 2011. I had some extra time until my defense was in September...I was having some fun with my kids but my wife took some general labor job at that time, to support us. (and my wife would [inaudible] from technical education, as she has a diploma in information technology)... plus I was trying to apply to get a job in the industry.

\section{Physical support}

Traditional gender roles of the patriarchal society assign certain duties to women such as childcare and housekeeping (Boyd \& Grieco, 2003). Those duties are often not recognized as work (Roseberg, 2001), and that is why physical support is not seen as women's contribution to their families' settlement. All participants in the research project "Integration Trajectories of Immigrant Families" immigrated to Canada with their children and/or had their children born in Canada. The adults in those families had to work to provide financial support, and perform physical work such as childcare and housekeeping. Lack of accessible childcare services in the Greater Toronto Area and lack of support of extended families put the major burden of raising children on women, as traditional caregivers. That allowed men to focus on earning income and building their professional careers. Tarik and his wife have four children, and he appreciated his wife's care of the whole family.

Tarik: That is the, thank God, I am lucky in that aspect I got. She did not put a burden on me. Even she uses to share. She was always, you know, encouraging me and she understood like after a twelve hour work, I am really tired. She did not do unnecessary demands and you know, sometimes, they say "Oh, please take care of us." During six months. No. Never. She was really, really supportive. 
The extended families of immigrants often helped to raise their children in the origin country. The respondents shared the burden of childcare with their parents and that made them not be so physically and emotionally stressed. The grandparents' care of children allowed working adults to continue their professional careers. After immigrating to Canada, those family duties had to be redistributed, and mainly women took the burden of taking care of their families due to traditional women family roles. The grandparents took care about their children and household issues, and thus allowed to pursue their professional career to the following female respondents, Olga and Lee.

Olga: When you are in your country your family is there all the time. On top of you and taking care of your children, sharing your life. Taking care of many things, back home. I used to have my mother [laughter] for everything. So she has to learn to live without me and I have to deal with my kids by myself. You know in our families that is very common. The grandparents they care of-- if you are working all the time.

Lee: I also need to take my older one, now that time she was only 20 months, more than one year, and in my back home, my in-laws helped me take care of my daughter, so I just go to work, come home and play with my kids, that is it! But here, I have to take care of everything by myself... I feel parenting skills, parenting is so tough for me, I need to improve my parenting skills

One of the female respondents, who established her family in Canada compared her settlement experience as a single person to that of a family with children. She stated that children would limit parents' settlement opportunities because the latter should care of their children and take any job to support them financially. A family with both parents saves money on childcare services because one of them takes care of children.

Agata:... now I can see how much different things are because we are two people. And I have a child now. So I can see that it makes a difference. Like if we have to drop off or pick up my child even now, if I was alone or a single mom, there is no way I would be able to stay here. Because I would have no one looking after my child.

Agata: Now, when I see other immigrants, I think that I was lucky to come without a family. Because if I had children I would have to start working on anything, right, because I would have to provide. When I think about it, it is really tough when you 
have children. And if you do not have family supporting you, you have to pay for child care. And if you cannot afford that you have to try to find a babysitter.

Childcare was the main reason why women of the studied families became housewives. Women in one of the surveyed families took care of their four children and performed other household duties, while a husband worked long hours. Another female respondent mentioned that childcare was their major settlement need. The women were unable to take regular classes at a language school due to childcare duties.

Tarik: After that she is doing everything. She is doing this, and yes she is really hardworking in the sense she has improved her English skills over here. Because with these kids, she was unable to join a school, so she did the LINC Home Study... No because, as I mentioned I was working 12 hours. She was not having lessons. She was having two kids.

Lee: we could not find a job.... That is the biggest thing. For me, I planned to look for a job, I think I can find a job, my language is okay, but I-no one to take care of my kids. My daughter, who can take care of my daughter? ... I think yeah, childcare is the biggest [challenge].

Women also cared of their families by performing other household duties such as cooking and cleaning. Overall, women's physical support of their family members contributes to their wellbeing while delaying women's settlement.

Jon: Every day she makes meals for me and my daughters and she also has a job as a school bus driver.

Lee: I cannot find proper, how do you say, service provider. Because you know, I need to focus on parenting my daughter, taking care of my daughter and family stuff so for me I do not have any more energy to work on developing networking, but if I can I think I could do a very good job in developing network

\section{Social support}

Immigrant women's social support of their husbands and children was very important for their settlement because it contributed to better adaptation of children to the new school system and their socialization; and women's social networks in Canada helped their family 
members to find employment. There are some barriers which keep immigrants away from active social life they used to have in their countries of origin: many hours of work to earn more money at low-paid jobs, language barriers, misunderstanding of the local culture and the type of personality of an immigrant. Immigrant women helped to settle their husbands by providing them with social ties and support. Lee told how her social connections helped to settle her family in Canada. Jon and Dawit highlighted the role of their wives in integrating their families into the local communities.

Lee: For example, when I landed in Toronto, I need to find day-care for my daughter, for my kids, for my older one. So, I have no much ideas, so I have to turn to the settlement worker in the settlement agency and also to make new friends to know which day care is good which is not that good. So communication is the best waythe fastest way to help you to get some information.

Lee: My husband, he tried [to find a job], but because of his personality, very reserved, very how do you say, yeah reserved guy. Stubborn guy ... So yeah, my husband. And my kids, I have told you, to help them build knowledge, and help them make the connection.

Jon: Yes, as I said my working life is like 50 or 60 hours a week, and as I said the language barrier too, and I have no background here, right? So, it is very hard to join the local community... Wife is social. She encouraged me to do something to do, so I applied for other areas. So I got many messages from her... Like, "you can do this, you can do that."

Dawit: Yeah, Individuals and some groups as well. My wife is socially active. She has friends ... . My wife is social able very nice. You know she made friend, so forth.

Socialization of immigrant children in the host community is one of the major concerns of parents. These are mainly mothers of the responding families who provided social support to their children by communicating to the school authorities to make their children be more confident and their transition period easier.

Fatima: For first week when he comes back from the school, he told me "I cannot understand anything..." I went to the school and I spoke with his teacher and his teacher told me "Do not worry, it isn't necessary that he do his homework, and only he is in the front and listen and I put him into ESL [English as Second Language]." After two weeks, he did not say anything. He was happy. 
Fatima: Yeah, even he [son] force me, "Come, Come and ask my teacher, how am I?" He like very much the teacher and student. He got award at the first year we came.

Jon: Because I cannot have time to help my daughters and I cannot help my daughters and my wife is also very busy, she supports my two daughters.

Tarik: Because she was not working and she was going to pick and drop the kids from the school. So she was having interaction over there. She was okay with the communication part.

The monocultural identity of immigrant children owned in the origin country changes to bicultural or multicultural through acculturation, "a combination of both old and new cultural values in which almost every aspect of behavior could change, including dress patterns, food habits, language, and other behaviors and values" (Berry, 2005, as cited in Khaleque, Malik, \& Rohner, 2015, p. 407). Communication with Canadian peers makes that process smoother for newcomer children. Immigrant mothers established relations with Canadian families with children to encourage acculturation of their children in Canada. Newcomer children replaced the social support of the relatives and friends left in their countries of origin with social connections and support of their peers and adults from the receiving community. It was easier for newcomers to build relations with people of the same cultural background and speaking the same language. Samia and her husband Ali immigrated to Canada with their three children. She made friends with families from her country of origin who had children of her daughters' age. That kind of her social support of her daughters helped the latter to establish social connections with the local community, learn about the new culture and adapt to the host environment easier.

Samia: For my daughters - there are a couple of friends because I made some friends from my cultural background. From my home origin country I made friends so their children - so their daughters, they are friends with my daughters.

Samia said she did not know any family with a child of the age of her son when they settled in Canada. The respondent argued that lack of social ties and friends in Canada 
together with unsociable personality made her son experience more difficult settlement period than his sisters did. He suffered from having no extended family members and friends around who could help him to overcome the cultural barriers and settle in the new community.

Samia: Definitely [the cultural change] affected them [children] because when my son came here [as a teenager] - he is not very friendly type person because everyone have different personality. So I realized--I saw him so many times when he was crying. Because there is no friend -- and also the [socio-economic] status of living goes down... The status changed and no family, no friend, so it was difficult for him and he was very upset about that.

Samia: But for my son, because all of the friends I made they have no kid like 20 year old or 18 year old, so it is still difficult for him. And he is just, as I mentioned, he is not very friendly...

Through communication with peers and their families, immigrant children learn cultural norms, values and models of behaviours in the host community. That experience contributes significantly to children's settlement and further integration into the Canadian community. Activities with children's friends and their families are another way how mothers contributed to development of their children's social ties. For this reason, Fatima encouraged her sons' hockey exercises and organized dinners with their friends.

Fatima: Yeah, they have dinner with each other, with their families. Even we have invited them and we have contacted them. Even in sometimes my son's go to his friends' families -- yeah most of them, they got friends'family. They have like fun, play some football, games with.

Fatima: Yes, I cannot believe that every night when they come back from the school. He forced me to go to hockey place because it was in middle school, like grade 8 at night. The school was very close to us. Every night I went with them to hockey players like court field.

One of the immigrant mothers, Kim, expressed her wishes to keep her son knowing the culture of their origin country but emphasized the importance of his acculturation and faster integration into the Canadian community. Therefore, she encouraged her son's 
socialization by sending him to the summer camp, where he may improve his English skills and knowledge of the Canadian culture.

Kim: I think my son will, has some big problem ... I am not sure, but I read some journal. As an immigrant, the student who are stay at home for summer vacation, their English level go down... After two or three months. It was a shock for me, because oh my God, I want to teach him English and [native language] both, so I use [native language] every day. But his English has a problem, it is a big deal. Yeah, in the summer vacation that is big problem. So usually my son goes to the summer camp for the whole summer vacation.

Kim: Because I cannot teach him about the Canada culture, Canada history, Canada ideas, Canadian minds, I cannot. I cannot teach him. He has to learn by himself from the outside, from his friends or schools, or camp, or other. So, yeah, I think he needed to join or attend other community, or other program, or other activities without me or my husband.

Relatives and friends often help newcomers to settle in Canada in the beginning.

Olga's brother helped to settle her family when she landed in Canada with her two children.

She was starting her own studies and asked her brother to settle her daughter in another city

where she was moving to study.

Olga: So I ask him [brother] that if he could go with her [daughter]. You know to help her to establish at the university for the second year. Because I went to the first year, you know? So he went, he went with her because he is in a better financial position you know. So we are that close. That I know I can count with him.

The respondent had good relations with her brother, which were the basis for good

relations developed among her brother and her daughter. The latter received a lot of social and emotional support from her uncle which was vital in her adaptation period.

Olga: With my daughter they have - my brother and my daughter? They have a closer relationship since we came here. They were not so close before because she was more like a child before. So she was more mature when we came here. Also she went through many difficulties in the process of adaptation. And he was always talking to her, so they became very, very close [name of daughter] and my brother. They are still very, very, close you know, so I will say that: it helps a lot the process of immigration because she experienced so many problems and he was always there to support her. 
Olga's brother had had good relations with his nephew before and in the beginning of their living in Canada, and tried to support the latter's settlement. Unfortunately, their friendly relationship was broken due to problems created by the nephew.

Olga: With my brother, yeah. So before we came here - they had an excellent relationship because my son, he looked up at my brother like as a father figure. And my brother, he was also looking after my son. But when we came here, my brother, he tried to support him a lot. Well, as my son he was so lost and he got into so many problems, that my brother, he was very upset with him and the relationship now is completely lost, I would say.

Women developed social networks and provided support to their family members in searching employment. Paulette referred her husband to his first employment in Canada. Adnan saw his mother's (Dasha) social support important for his employment and networking, and overall to his adaptation period in Canada.

Paulette: The temporary agency that I worked with at first. I recommended him [the husband] well I had spoken to the employer before and they said "Alright, when he comes, have him come in," and so and on. He got off the ground running which was good. So that was not a major challenge for us.

Adnan: She was the only one that spoke English, she was the only one that kind of knew how the Canadian system was. My mom is very-- She adapts to societies as quick as she can ... So my mom was the number one resource, she helped me find a job, she helped me get connected, volunteer.

\section{Emotional support}

The literature review and the respondents confirmed that immigrants' main stressors in the settlement period were job searching, a lower socio-economic status in Canada comparing to that in their country of origin, language and other cultural barriers. Before coming to Canada, the respondents had expected to find jobs in their previous fields easily due to their professional skills and experience, for which they had been admitted to Canada. However, they were stressed with difficulties they faced on the way to their skilled employment and needed emotional support to avoid depression and keep fighting for the 
well-being of their families. Women provided that support to their husbands and that was one of their major contributions to their families' settlement.

Lee: We thought maybe, you know? I have my English degree, my husband, IT project manager, I think for us, maybe it would be easier to look for job. But when I came here I thought "Oh my goodness," totally different! We could not believe the website. On the website [of the Country of Origin] it said "Oh your occupation skill, your husband, I.T., very good."

Tarik: Yeah that was very good. That was very good. She is very supportive and she is very, as I mentioned, the person who stay according to situation. That kind of personality. She is, me too. So she knew that all the - We were having very good life all over there but over here she knew that the situation is not the same... She was always, you know, encouraging me.

Losing a job might also cause deep stress for immigrants because employment is vital for financial wellbeing of the whole family, so they have to be emotionally ready to overcome the labour market barriers again and get employment:

Omar: ... because after leaving the job, I was mentally very much disturbed.

Amit: She supported me a lot with financial support also, emotional support, in all respect.

Mental health professionals might help to overcome emotional stress of immigrants.

However, the lack of knowing the Canadian culture and the policy of confidentiality, language and cultural barriers, and the perception of this kind of services in their home communities make immigrants stay away from the professional help.

Samia: There, actually, there are services [to help them with their mental health issues] but the thing is, like for example back home if you go to some mental health place. People think you are mad... There is a stigma. Over here, they do not know if they go there so everybody will know about this.

Samia: But only again, the problem is if they do not know how to speak in English, how they will... Those services and how they will explain how they are feeling. You know? So the language barrier is still there...

Therefore, immigrants preferred to tell about their worries and problems in the new environment to someone, who shared the same cultural, social and immigrant background, 
and thus, could understand them and support. The latter were often their immediate family members.

Amit: I would thank God in this matter, I am lucky that we had very well-made, closely assisted emotionally attached family; we care for each other without asking. And that is a place, I think I mentioned that, that kind of family, and that kind of support... It is very well-knit family and it is rather teamwork. That is the basic, or you can say, depend on each other and are always available for each other.

The age is another immigrants' stressor because they see their age of over 45 years old as another barrier for their skilled employment, while the long professional careers were their advantage at the home country.

Jon: Because I got some information from someone, telling me that, you have no problem working with the company, but your age - I think that my age is blocking me of getting a new job. So I wanted at the time to get more experience, so I wanted to just volunteer, but they did not give me the chance.

It was important for those respondents to receive emotional support from their wives on time, who believed in their husbands and encouraged them to move further. Fatima supported her husband in his employment searches.

Fatima: Yeah for first year we were like okay. After three or four months I saw that he wants to sit at home, that is it. I told him "No you have to go out and find a job. It does not matter which - because we have to settle ourselves first." So he went. He told me "No, nobody give me job in my age," like that. When I find job, I told him "See? I found a job in my age, so you can." And then he went to [the workplace], three or four times. Then he spoke with them. After two or three times, they accept him.

Immigrants often take courses or enroll in certificate or degree granting programs at Canadian universities and colleges in order to receive domestic educational credentials and improve their employability. Studying takes many resources of immigrants: money, time, physical and emotional, so they need their spouses' support.

Lee: Yeah, for example, my husband I support him. I am how do you say, not financial, I mean the spiritually. You know, now my husband he is over forties, yeah. 
And we have family and we have small kids, but he likes to pursue study at [University]. Oh, I encourage him, "Go! Try it! If you can get it, if no, continue, keep trying."

Immigrant women also provide emotional support to their children in their settlement period, who face language and cultural barriers at school. Better future opportunities and education for their children were the main reason for respondents to immigrate to Canada.

Arash: And I felt that Canada could be the place where my son can basically get his education and have that opportunity to make something out of his life, make something for himself. And basically, I would say $70 \%$ of my decision relied on my son.

Amit: Education and social security - reasons to come...

Samia: Actually when we were in our home country we realized that it would be harder for us to provide our children a good quality education and so that's why we moved to Canada. For the education purposes, for our children.

Mothers encouraged their children to keep studying and learn the new culture and language. Emotional support of Fatima lessened her son's stress due to cultural changes and helped him to adapt to the environment.

Fatima: When I spoke with him-you know the culture you have, you can accept very easily in this culture. You can learn English very easily. I explain everything for him. Every day he does not have any problem because he accepts very soon.

Due to traditional duties of women as primary caregivers in their families, children often receive physical, emotional and social support mainly from their mothers because fathers' roles are often limited to breadwinning. Therefore, mothers develop strong emotional ties with children and that is why children could feel more comfortable to share their problems and concerns with mothers than with fathers. Adnan and his siblings said their mother Dasha contributed a lot to their settlement in Canada.

Adnan: My dad? Not so much. He looks at me, as more of a second hand. So, for me to show him any kind of weakness is-- like my mom was the resource for any problem. 
Lack of English language skills is the main obstacle for newcomer children at school. Moreover, children have different personalities, skills and families which could contribute to their faster adaptation to the new environment or not. The experience of Olga shows that children of the same family and age range may settle differently and they need her permanent emotional support.

Olga: My daughter, she did very well but the first year it was very traumatic for her. She did not feel she fit here. The guy was okay but she was bad. Then after one year she was okay and he really crashed. And until now, I am still struggling with him because he never felt that - he never adjusted very well because he has issues with the English.

Unfortunately, immigrants sometimes had to deal with perceived insensitivity of school teachers, which slowed down or even put barriers for newcomer children's adaptation at school in Canada. One of the responding newcomer mothers Olga told about her children adaptation experience at school, when her son's efforts supported by his mother were undermined by the teacher and the classmates.

Olga: I remember like a couple years, maybe after one year, two years when we were here, the teacher asked him to read in front of all the class. And he tried to-- we have a strong accent you can see, you know. He tried to read and everybody was laughing and even the teacher was laughing, saying, "Sit. Sit, do not, never mind." Something like that. It was just shocking. Of course, it was traumatizing for him because he was a teenager. He was trying his best and everybody laughing plus the teacher [saying] never mind ... So he just did not want to come back to the class. And that experience, and the frequent experience of having the guidance counselors in the schools pushing them down ...

This mother provided great emotional support to her children by persuading them that they were free to choose what to study and in which field to build their careers, they should not give up and achieve their goals. She assumed that one of the possible reasons why school authorities discouraged her children to pursue higher education was the teachers' "low expectations" of their ethnic community based on the statistical data. Her emotional support 
was important for her children and encouraged her daughter to apply for the program to the university where she wanted to study despite negative reactions of others.

Olga: ... because of that you should be supportive and try to encourage them. I used to say my daughter, she wants to study that program and they were like, "Oh, maybe music, maybe literacy, maybe -" I mean literature. "Maybe -" No, she is going to study that program, she is going to this university.... My daughter now, she is in the university studying marine biology as we say. Not will all of them happened the same because not all the kids are strong enough. But she had to fight a lot, with schools, with the teachers, with guidance counsellors, to get what she wanted. 


\section{Discussion and Conclusion}

This study found that women's support of their families made a significant contribution to their settlement in Canada. The analyzed narratives of the respondents demonstrated that women's financial, physical, emotional and social support allowed their family members to develop social connections and network, overcome their emotional problems, and concentrate their resources on studies, job searching and other settlement goals.

The neoliberal immigration and settlement policies and programs applied in Canada shifted the focus from families to individuals (Brown, 2003), which disadvantaged newcomer families because they lacked the family-oriented support from settlement organizations and policy makers. Meeting the immigration criteria for economic class immigrants such as proper education, work experience and language skills of the principal applicant do not ensure his or her own and their families' successful settlement in Canada. The respondents admitted they felt helpless in facing major settlement problems such as barriers toward employment in the desired position and field, cultural change and language problems. They recognized an important contribution of women, as a mother and wife, in overcoming those difficulties in the settlement period.

Employment of immigrant women allowed their families to satisfy their needs in housing, food and education. Like Nichols and Tyyska (2015) study, I found that women shared the breadwinning duties with their husbands and sometimes were the main income earner in the family. Long working hours restrained women from pursuing their professional career they had had in their country of origin. I also found that the respondents admitted that simultaneous settlement of both spouses was often difficult, and it was mainly the woman, sacrificing her own settlement to allow a husband and children to settle faster. 
The lack of available childcare services and help of the extended families, discussed by Friendly (2014) and Chen (2011) respectively, made women of the surveyed families stay at home to take care of their children. The men and children appreciated that contribution of their wives and mothers. Therefore, the husbands could focus on their employment and studies while their wives took care of children.

Unlike previous studies, I found examples how newcomer women's social support helped their family members to adapt to the receiving environment smoother. They interacted with the school authorities, established friendly relations with other families with children and organized events like dinners to encourage their children and husbands to learn about the Canadian culture and integrate into the local community. The social networks of two female respondents helped their family members to find first employment in Canada.

Emotional support provided by immigrant women to their families was highly valued by the latter. The women encouraged their husbands in their studies and job searching efforts by telling them not to give up, not to think of their age and lack of local work experience as the major barriers towards their employment. Emotional support of women helped their husbands and children to lessen their stress and continue to integrate into Canadian society. Children often had closer emotional ties to their mothers as to their primary caregivers, whose support and positive attitude towards acculturation encouraged the formers to adapt to the new school environment and move forward to their goals in education, sports and overall settlement. Like in the study of Colbert (2012), one of the respondent mothers said her children had been discouraged by teachers who had low expectations and were not supportive in her children's study efforts.

Overall, women made significant contribution to their families' settlement in Canada by supporting them financially, taking care of their children and husbands, providing 
emotional and social support. All these benefitted settlement of immigrant families but sometimes delayed women's own settlement and resulted in their further deskilling due to their inability to combine their family duties and settlement activities such as language courses and trainings required to return to their previous careers. Lack of available childcare services in the Greater Toronto Area and patriarchal assumptions of gendered household duties were one of the main barriers towards women's settlement. All women in the responding families had post-secondary education and work experience in skilled occupations in their countries of origin. They had expected to continue working in their professional fields but settlement needs of their families, social inequality maintained by public patriarchy and traditional family roles assigned by private patriarchy of their original culture made most women prioritize their families' settlement and limit their roles to breadwinners, housekeepers and mothers.

My study was limited because it was based on the secondary data of the research project "Integration Trajectories of Immigrant Families," which was not focused on studying women's roles in immigration and settlement experience of their families. Not all questions and given information were relevant to my study. Further work needs to be done to study women's contribution to their families' settlement with the aim to understand how it helps to meet the settlement needs of their families and how that support could be facilitated for the benefits of immigrant families and the society through changes in immigration policies, programs and services.

The respondents said their extended families like parents and siblings had provided significant emotional and physical support while they were living in their countries of origin. Lack of that support in Canada, due to the immigration policy restrictions of who may apply for immigration with the main applicant, made newcomers solve the problem of lack of 
available childcare services alone and mainly at the expense of women. Newcomer women stayed at home to take care of children and thus their own settlement was slow, experienced deskilling and social isolation in the receiving society. The immigration policies and programs should become family-oriented and add parents of the principal applicant and his/her spouse to the list of who may immigrate with them. That would allow working-age newcomers to take all settlement opportunities with the support of their parents.

The federal government should solve the problem of unavailable child care services in most provinces by adopting the national child care program in Canada (Friendly, 2014). It would contribute to the settlement of newcomer families and in particular women. The working-aged immigrant women will be able to take language courses, trainings and studies, join the labour market and contribute more to settlement of their families if they have access to daycare centres for their children.

Settlement organizations should offer integration courses designed for women and parents like in Germany, France, Spain and New Zealand (Shields et al., 2016). Those courses should introduce cultural and parenting practices in Canada and equip women and immigrant families with knowledge such as how to facilitate children's adaptation to the new environment. Integration through sports is another opportunity for immigrant children and their parents to interact with Canadian families and develop their social connections (Shields, et al., 2016).

The support of women's settlement by policy makers and settlement organizations may produce a multiplier effect on the settlement experience of whole families. Newcomer women with strong language skills and knowledge of Canadian culture will achieve the previous socioeconomic status faster and thus would better facilitate their family members' integration into the receiving society. The Canadian economy does not gain all the benefits of 
hosting foreign skilled workers in the long term and thus, will not be able to acquire the comparative advantage on account of the human capital of newcomers. The consequences of low public support of settlement and other social services for skilled immigrants and their families are their further deskilling, financial instability, possible health problems as a result of stress, and overall poor settlement and integration into the Canadian community. The macroeconomic costs of poor family settlement are higher unemployment and poverty rates, more spending on welfare programs (Biles, Burstein, \& Frideres, 2008). 


\section{References}

Ali, M.A. (2015). The schooling of children of immigrants. In H. Bauder and J. Shields (Eds.), Immigrant experiences in North America: Understanding settlement and integration (pp. 273-291). Toronto: Canadian Scholars Press.

Ali, M.A., Kobayashi, A., Cliff-Jungling, S., Ochocka, J., Lomotey, J., Araujo, L., \& Kljujic, D. (2012). Making Ontario home 2012. Ontario Council of Agencies Serving Immigrants. Retrieved from http://www.ocasi.org/downloads/OCASI_MOH_ENGLISH.pdf

Ali, M.A., Corson, P., \& Frankel, E. (2009). Listening to families: Reframing services. Toronto: Chestnut Publishing Group.

Aycan, Z., \& Kanungo, R.N. (1998). Impact of acculturation on socialization beliefs and behavioral occurrences among Indo-Canadian immigrants. Retrieved from http://zeynepaycan.net/doc/j26.pdf

Biles, J., Burstein, M., \& Frideres, J. (2008). Introduction. In J. Biles, M. Burstein, \& J. Frideres (Eds). Immigration and integration in Canada (pp.3-18). Kingston: School of Policy Studies, Queen’s University.

Bonifacio G. (2012). Introduction. In G.T. Bonifacio (Ed.). Feminism and migration: Cross cultural engagement. Retrieved from https://link-springercom.ezproxy.lib.ryerson.ca/chapter/10.1007/978-94-007-2831-8_1

Boyd, M., \& Grieco, E. (2003). Women and migration: Incorporating gender into international migration theory. Migration Policy Institute. Retrieved from http://www.migrationpolicy.org/article/women-and-migration-incorporating-genderinternational-migration-theory 
Bradbury, B. (2001). Gender at work at home: Family decisions, the labour market, and girls' contributions to the family economy. In B.J. Fox (Ed.) Family patterns, gender relations (pp. 108-125). Don Mills: Oxford University Press Canada.

Brown, W. (2003). Neo-liberalism and the end of liberal democracy. Theory \& Event, 7 (1). Retrieved from http://muse.jhu.edu.ezproxy.lib.ryerson.ca/article/48659

Castilla, E. J., Lan, G. J. and Rissing, B. A. (2013), Social networks and employment: Mechanisms (Part 1). Sociology compass, 7, 999-1012. Retrieved from http://onlinelibrary.wiley.com.ezproxy.lib.ryerson.ca/doi/10.1111/soc4.12096/full

Chen, N. (2011). Multigenerational families provide benefits for everyone. Retrieved from http://missourifamilies.org/features/divorcearticles/relations72.htm

Chui, T. (2011). Immigrant women. Statistics Canada. Retrieved from http://www.statcan.gc.ca/pub/89-503-x/2010001/article/11528-eng.htm\#a3

Colbert, J.A. (2012). The Settlement of young newcomer children: Perspectives for policy and program development. In H. Bauder (Ed.), Immigration and settlement: Challenges, experiences, and opportunities (pp. 297-310). Toronto: Canadian Scholar's Press.

COSTI Immigrant Services (n.d.). Programs and services. Retrieved from http://www.costi.org/programs/program_services.php

Donato, K.M., and Gabaccia, D. (2016). The global feminization of migration: Past, present, and future. Migration Policy Institute. Retrieved from http://www.migrationpolicy.org/article/global-feminization-migration-past-presentand-future

Federal Office for Migration and Refugees (2015). Integration course for women. Retrieved from 
http://www.bamf.de/EN/Willkommen/DeutschLernen/Integrationskurse/SpezielleKur sarten/Frauenkurse/frauenkurse-node.html

Friendly, M. (2014). Child care — the ramp that provides equal access to the workforce for mothers. Retrieved from http://www.childcarecanada.org/sites/default/files/FEWO\%20brief\%20Nov\%2027\%2 02014.pdf

Fox, B.J. (2001). Reproducing difference: Changes in the lives of partners becoming parents. In B.J. Fox (Ed.), Family patterns, gender relations. (pp. 287-302). Toronto: Oxford University Press

Frisken, F., \& Wallace, M. (2000). The response of the municipal public service sector to the challenge of immigrant settlement. Retrieved from http://atwork.settlement.org/downloads/Municipal_Sector.pdf

Gabriel C. (2004) A question of skills: Gender, migration policy and the global political economy. In K. van der Pijl, L. Assassi \& D. Wigen (Eds.), Global regulation: Managing crises after the imperial turn (pp. 162-176). UK: Palgrave Macmillan.

Girard, E.R., \& Bauder, H. (2007). Assimilation and Exclusion of Foreign Trained Engineers in Canada. Antipode, 39 (1), 35-53. Retrieved from http://journals2.scholarsportal.info.ezproxy.lib.ryerson.ca/details/00664812/v39i0001/ 35_aaeoftciapro.xml

Government of Canada (2017). Language classes funded by the Government of Canada. Retrieved from http://www.cic.gc.ca/english/newcomers/live/language.asp Government of Canada (2016). Annual report to Parliament on Immigration. Retrieved from http://www.cic.gc.ca/english/resources/publications/annual-report-2016/index.asp 
Government of Canada (2005). Recent immigrants in metropolitan areas: Canada—A comparative profile based on the 2001 census. Retrieved from http://www.cic.gc.ca/english/resources/research/census2001/canada/partc.asp Hondagneu-Sotelo P. (2000). Feminism and migration. The Annals of the American Academy of Political and Social Science, Feminist views of the social sciences, 571, 107-120. Retrieved from http://www.jstor.org/stable/1049137?seq=1\#page_scan_tab_contents

Hudon, T. (2015). Women in Canada: A Gender-based statistical report - Immigrant women. Statistics Canada. Retrieved from http://www.statcan.gc.ca/pub/89-503x/2015001/article/14217-eng.pdf

Jamarani M. (2012). Encountering differences: Iranian immigrant women in Australia. In G.T. Bonifacio (Ed.). Feminism and migration: Cross cultural engagement. Retrieved from https://link-springer-com.ezproxy.lib.ryerson.ca/chapter/10.1007/978-94-0072831-8_8

Jimeno, C., Martinovic, J., Gauthier, M., Bouchard, H., \& Urquhart, D. (2010). Immigrant children, youth and families: A qualitative analysis of the challenges of integration. Retrieved from https://www.spcottawa.on.ca/sites/all/files/pdf/2010/Publications/Immigrant-FamilyReport-English.pdf

Kelley N., \& Trebilcock M. (2010). The making of the mosaic: A history of Canadian immigration policy (2nd ed.). Toronto: University of Toronto Press, Scholarly Publishing Division

Khaleque A., Malik F., \& Rohner R.P. (2015). Differential acculturation among Pakistani American immigrant parents and children. Psychological Studies, 60 (4), 407-411. 
Retrieved from https://link-springer-

com.ezproxy.lib.ryerson.ca/article/10.1007\%2Fs12646-015-0337-3

Kilbride, K.M., \& Ali, M.A. (2010). Striving for voice: Language acquisition and Canadian immigrant women. Current Issues in Language Planning, 11(2), 173-189. Retrieved from https://journals-scholarsportalinfo.ezproxy.lib.ryerson.ca/pdf/14664208/v11i0002/173_sfvlaaciw.xml

Knapp, J., Muller, B., \& Quiros, A. (2009). Women, men, and the changing role of gender in immigration. Institute for Latino studies, Student research series, 3(3), 1-13.

Retrieved from https://latinostudies.nd.edu/assets/95245/original/3.3_gender_migration.pdf

Lawrence, J.A., Collard, A.H., \& Kaplan, I. (2013). Understanding the wellbeing of children: what helps children from refugee, immigrant and local backgrounds feel better. In K.D. Gioia and P.Whiteman (Eds.), Children and Childhoods 3: Immigrant and Refugee Families (pp.111-133). Newcastle upon Tyne: Cambridge Scholars Publishing.

Lindsay L, \& Findlay A. (2001). Migration of highly skilled persons from developing countries: Impact and policy responses. International Labour Office: International Migration Branch. Retrieved from http://www.ilo.org/wcmsp5/groups/public/--ed_protect/---protrav/---migrant/documents/publication/wcms_201706.pdf

Morissette, R., \& Galarneau, D. (2016). Economic insights: Labour market participation of immigrant and Canadian-born wives, 2006 to 2014. Retrieved from http://www.statcan.gc.ca/pub/11-626-x/11-626-x2016055-eng.htm 
Ng-See-Quan, K. (2013). Racialized and immigrant women in cities. Women and urban environments. Retrieved from http://www.twca.ca/wpcontent/uploads/2013/02/Racialized_and_Immigrant_Women_in_Cities.pdf

Nichols, L., \& Tyyska, V. (2015). Immigrant women in Canada and the United States. In H. Bauder and J. Shields (Eds.), Immigrant Experiences in North America: Understanding Settlement and Integration (pp. 248-272). Toronto: Canadian Scholars Press.

Ontario Canada (2016). Bridge training programs. Retrieved from http://www.ontarioimmigration.ca/en/working/OI_BRIDGE_EMPLOYER.html Public Health Agency of Canada (PHAC) (2006). The human face of mental health and mental illness in Canada 2006. Retrieved from http://www.phacaspc.gc.ca/publicat/human-humain06/5-eng.php

Raghuram, P. \& Kofman, E. (2004). Out of Asia: Skilling, re-Skilling and deskilling of female migrants. Women's Studies International Forum, 27:2. Retrieved from http://journals2.scholarsportal.info.ezproxy.lib.ryerson.ca/pdf/02775395/v27i0002/95 _ooasradofm.xml

Robert, A., \& Gilkinson, T. (2012). Mental health and well-being of recent immigrants in Canada: Evidence from the Longitudinal Survey of Immigrants to Canada (LSIC). Retrieved from http://www.cic.gc.ca/english/resources/research/mental-health.asp

Root J., Gates-Gasse E., Shields J., and Bauder H. (2014). Discounting immigrant families: neoliberalism and the framing of Canadian immigration policy change. RCIS Working Paper No. 2014/7. Retrieved from http://www.ryerson.ca/content/dam/rcis/RCIS-WP-Root-No2014-7.pdf 
Roseberg, H. (2001). Motherwork, stress and depression: The costs of privatized social reproduction. In B.J. Fox (Ed.), Family patterns, gender relations. (pp. 303-316). Toronto: Oxford University Press.

Salem J.M. (2012). Exploring the activism of immigrant Muslim women in Chicago: Continued frontiers of engagement. In G.T. Bonifacio (Ed.). Feminism and migration: Cross cultural engagement. Retrieved from https://link-springercom.ezproxy.lib.ryerson.ca/chapter/10.1007/978-94-007-2831-8_15\#Fn2_15

Sangster, J. (2011). Through feminist eyes. Edmonton: AU Press, Athabasca University Shapaizman I. (2010). The influence of neo - liberal ideas and political conflict on the privatization process of immigrant policy: A comparison of Israel, Canada and the Netherlands. Retrieved from http://www.umdcipe.org/conferences/Maastricht/conf_papers/Papers/The_influence_o f_neo\%96liberal_ideas.pdf

Shields, J., Drolet, J., \& Valenzuela, K. (2016). Immigrant settlement and integration services and the role of nonprofit providers: A cross-national perspective on trends, issues and evidence. Retrieved from http://www.ryerson.ca/content/dam/rcis/documents/RCIS\%20WP\%202016_01\%20Sh ields\%20et\%20al\%20final.pdf

Simich, L., Beiser, M., Stewart M., Mwakarimba E. (2005). Providing social support for immigrants and refugees in Canada: Challenges and directions. Journal of Immigrant and Minority Health, 7(4), 259-268. Retrieved from https://link.springer.com/article/10.1007\%2Fs10903-005-5123-1 
Statistics Canada (2016). Labour force characteristics by immigrant status of population aged 25 to 54 , and by educational attainment. Retrieved from http://www.statcan.gc.ca/tables-tableaux/sum-som/101/cst01/labor90a-eng.htm

Steger M.B., \& Roy R.K. (2010). Neoliberalism: a very short introduction. Oxford University Press. Retrieved from http://www.veryshortintroductions.com.ezproxy.lib.ryerson.ca/view/10.1093/actrade/ 9780199560516.001.0001/actrade-9780199560516

Stewart M.J., Makwarimba E., Beiser M., Neufeld A., Simich L., \& Spitzer D. (2008). Social support and health: immigrants' and refugees' perspectives. Diversity \& Equality in Health and Care. Retrieved from http://diversityhealthcare.imedpub.com/socialsupport-and-health-immigrants-and-refugees-perspectives.php?aid=2006

Tastsoglou, M., \& Preston, V. (2005). Gender, immigration and labour market integration: Where we are and what we still need to know. Atlantis, 30.1. Retrieved from http://journals.msvu.ca/index.php/atlantis/article/viewFile/858/851

Toro-Morn, M., Guevarra, A.R., \& Flores-González, N. (2013). Introduction: Immigrant women and labor disruptions. Retrieved from http://ebookcentral.proquest.com.ezproxy.lib.ryerson.ca/lib/ryerson/reader.action?doc $\mathrm{ID}=3414284 \& p p g=1$

Uzair A. (2014). Why immigrants want to leave Canada: The struggle of Canadian university graduate immigrants in the labour market. Retrieved from https://macsphere.mcmaster.ca/bitstream/11375/16042/1/Ambreen\%27s\%20MSW\%2 0Thesis.pdf

Valade, M.Y. (2017). Methodology. Retrieved from http://www.ryerson.ca/immigrant_families/publications/ 
Walby, S. (1990). Theorizing patriarchy. Cambridge: Blackwell. 